Original Research Paper

\title{
Water Reuse in Industry: Necessities and Possibilities
}

\author{
Kaveh Ostad-Ali-Askari and Saeid Eslamian
}

Department of Water Engineering, Collage of Agriculture, Isfahan University of Technology, Isfahan, Iran

\author{
Article history \\ Received: 24-06-2018 \\ Revised: 19-01-2019 \\ Accepted: 21-01-2021 \\ Corresponding Author: \\ Kaveh Ostad-Ali-Askari \\ Department of Water \\ Engineering, Collage of \\ Agriculture, Isfahan University \\ of Technology, Isfahan, Iran \\ Email: kaveh.oaa2000@gmail.com
}

\begin{abstract}
To begin with, lack of water, declining quality of it and environmental restrictions caused to increase requirements of reusing wastewaters extremely. By industrialization and reduction of pressure on water sources, using water in industry has adequate potential to reduce costs in saving water and treatment of wastewater. Wastewater can be recycled direct and indirect based on the type and quality. There are different ways to reuse water according to progressed technology these days. Furthermore, using intelligently and reusing water with ultimate use of missed water in environment present a growing challenge in industrial management. According to availability restrictions of fresh water sources and their protection requirement, implementation of water recycling plans in water sustainable management strategy is crucial. By progressing of industrializing in developed countries, water consumption in industry has been increased simultaneous by five principal factors. One of the methods of limiting water consumption is reuse wastewater. Reduction of water consumption by industrializing can diminish water removal from local resources. Therefore, enhancement of water availability and improvement of social relations, increasing of input water's efficiency, lowing off wastewater discharge and their pollutant loads, decrease expenses of thermal energy and process of principal costs are the most crucial factors. Finally, reusing of wastewaters has adequate potential for decreasing costs of any project as well as wastewater treatment.
\end{abstract}

Keywords: Water Reuse, Wastewater, Recycle, Industry, Water Consumption

\section{Introduction}

To begin with, there are substitutions for oil or other natural sources but nothing could be a substitution for water. Because of water shortage problems which world and especially the drought areas of world are encountered with, experts are trying constantly to present approaches to stock water as much as possible. Developing countries have crucial plans to manage water sources such as: Softening sea water, modernization of agriculture and changing cultivate patterns, treating consumed water and recycle wastewater, rehabilitation of water transmission network (Lazarova, 2001). Water recycle means cleaning and using waters such as urban swage, industrial swage or gray water for non-drink consumptions such as industrial, sanitary, irrigation, green spaces, gardens, cooling towers (Illungkoo and Vigneswaran, 1998) Water reuse cause to reduce dependency of citizens upon rain fall, improvement of river health and maintaining wealth of river water and dams for drink consumption. Furthermore, all sorts of wastewaters possess potential to not only hurt humans' health but also contaminate environment. However, they could be converted into a valuable source by proper management and applying in appropriate process (Abdel-Shafy et al., 2013). Nowadays, using of recycled water as a source to supply more water is being encouraged. These days, only few percentage of wastewater around the world are treated and used. Today, water reuse consists of following groups practically: 
- Irrigation water reuse

- Treat and discharge in river for downstream consumption

- Urban water reuse (supply drink and non-drink water and irrigate of green spaces, lands

- Industrial water reuse

- Augmentation of Underground water

Agriculture is one of the biggest water consumers in the world and approximately $95 \%$ of water sources of developed country are used for agriculture (Asano et al., 2006). In United States of America almost 35\% of clean water are consumed for agriculture. Also thermoelectric consumes $49 \%$ of supplied waters. Industry use less proportion which is about $5 \%$ of supplied waters that it is still shown a huge volume of using fresh water. Therefore, industry has an important role in limiting water consumption. Today, most of industries and factories are trying to reuse their own used water to decrease the amount of water consumption (Gohari et al., 2013). Water reuse and water recycle are two processes which the wastewater might have either different source or same source from the using source. Industrial wastewater could be recycled in either the place of wastewater production or outside of that and could be used again in the same industry. Treatment of wastewater is crucial environmentally due to it prevents the condition of drought areas and natural ecosystems to become more critical. Water reuse in industry has been searched widely (Mattioli et al., 2005). Textile industry consumes large amounts of primary water (average value of $160 \mathrm{~m}^{3} / \mathrm{t}$ of finished textile) which is normally discharged as waste after required treatments in on-site facilities or in centralized municipal plants (Eslamian et al., 2015a; 2015b).

Reused water can be used in various industries such as: Paper industry, textile industry, poultry, greenhouses and gardening, irrigation in agriculture, cooling towers.

\section{Iron and Steel Industry}

Water treatment has been problematic constantly in steel and iron industry due to the high amount of use and high heat which is applied to the water in foregoing industry. Use of water is indispensable in some part of iron and steel industry such as pelletizing of sinter mix, making of green pellets during the production of iron ore pellets, production of steam and hence power and granulation of blast furnace slag (Williams, 1982). Therefore, this huge use of water leads to more contamination which contain dissolved substances and chemical and suspended solids. The following Table 1 illustrates the water quality guidelines for the reuse of water in steel and iron industry (Bilotta et al., 2017).

A survey in 2011 reports that, each steel plant receive $28.6 \mathrm{~m}^{3}$ water per ton in average and in following that $25.3 \mathrm{~m}^{3}$ water is discharged. It concludes the low percentage of total water consumption which is approximately 1.6 to $3.3 \mathrm{~m}^{3}$ and huge amount of water is vanished because of evaporation (Williams, 1982). The following chart demonstrates amount of intake, discharge and consumption of water in some steel plants in 2011 (Fig. 1 and 2).

Table 1: Water quality guidelines for the iron and steel industry

Concentration (mg. $\mathrm{L}^{-1}$ )

\begin{tabular}{|c|c|c|c|c|c|}
\hline Parameters & $\begin{array}{l}\text { Hot-rolling, } \\
\text { quenching, } \\
\text { gas cleaning }\end{array}$ & Cold-rolling & Softened & Demineralized & $\begin{array}{l}\text { Steel } \\
\text { manufacturing }\end{array}$ \\
\hline $\mathrm{pH}$ & $5.0-9.0$ & $5.0-9.0$ & $6.0-9.0$ & - & $6.8-7.0$ \\
\hline Dissolved solids & $<25$ & $<10$ & ND1 & ND & - \\
\hline Settleable solids & $<1000$ & $<1000$ & ND & ND & _- \\
\hline Dissolved oxygen & $\begin{array}{l}\text { (Minimum for aerobic } \\
\text { conditions) }\end{array}$ & & & & \\
\hline Temperature & $<38$ & $<38$ & $<38$ & $<38$ & $<38$ \\
\hline Hardness & $\mathrm{NS}^{\mathrm{bc}}$ & NS & $<100$ & $<0.1$ & $<50$ \\
\hline Alkalinity & $\mathrm{NS}^{\mathrm{c}}$ & $\mathrm{NS}^{\mathrm{c}}$ & $\mathrm{NS}^{\mathrm{c}}$ & $<0.5$ & - \\
\hline Sulfate & $<200$ & $<200$ & $<200$ & _- & $<175$ \\
\hline Chloride & $<150$ & $<150$ & $<150$ & ND & $<150$ \\
\hline Oil & NS & ND & ND & ND & ND \\
\hline Floating material & NS & ND & ND & ND & ND \\
\hline
\end{tabular}


WATER CONSUMPTION IN 6 STEEL PLANTS in 2011

$\left(\mathrm{M}^{3}\right.$ WATER/PER TON)

|| Intake |Discharge||Consumption

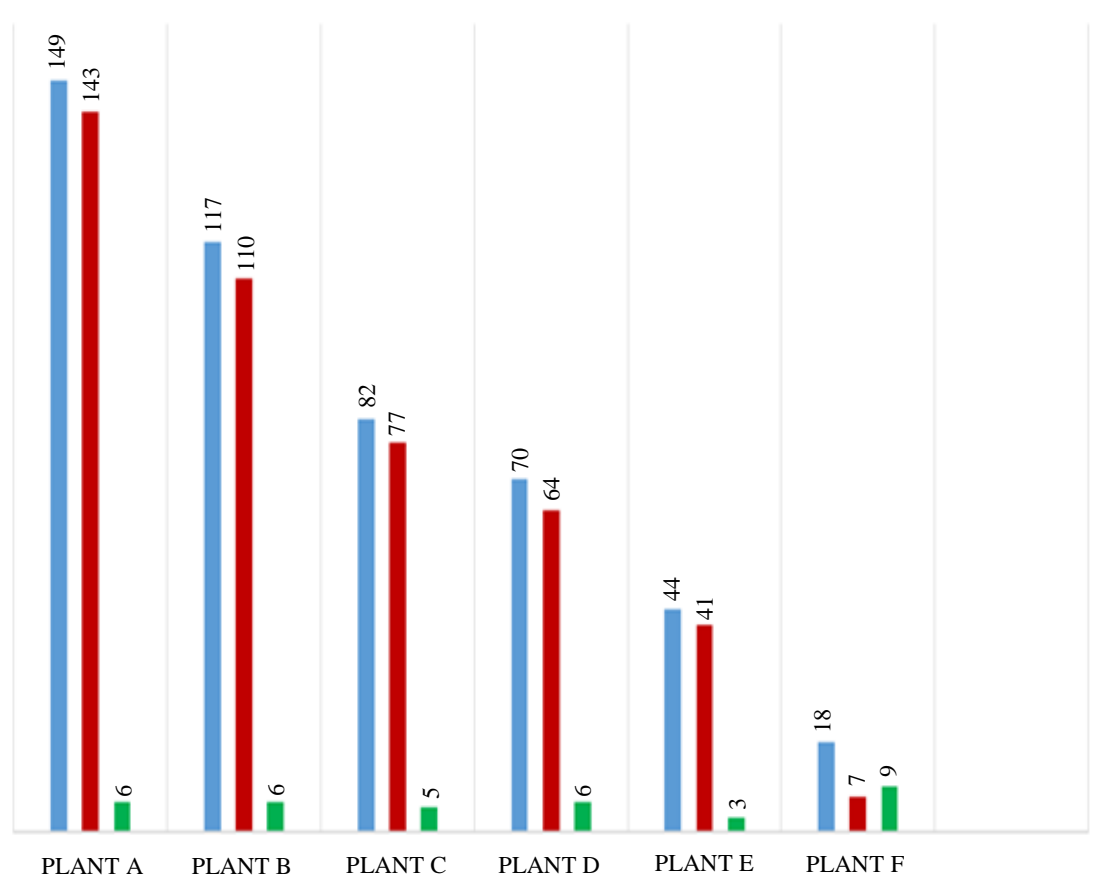

Fig. 1: Water consumption in some parts of steel industry in 2011

WATER CONSUMPTION OF PAPER

INDUSTRY IN SOME COUNTRIES (\%)

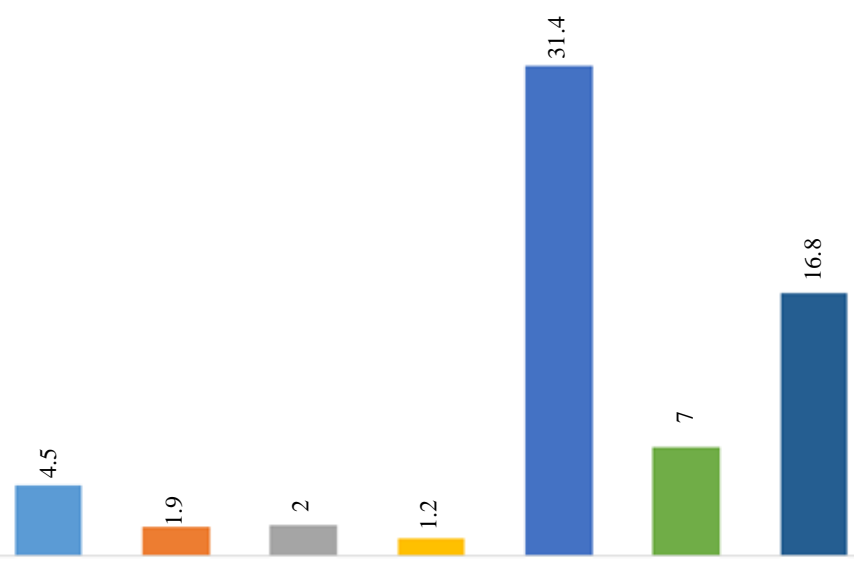

Fig. 2: Assigned water for paper industry in some European countries 


\section{Paper Industry}

In the early phases of paper industry, high amount of water was needed to produce papers. But the industry has been improved in recent years due to economic and ecological improvements (Abdel-Shafy et al., 2013). The below bar chart illustrates the allocated percentage of water which is consumed for paper industry out of all industries in some European countries.

Nowadays, because of increasing environmental anxieties and legal restrictions, cellulose and paper industry are constrained to decrease their own water consumption. Generally, wastewater of paper factory is treated biologically. The quality of discharged wastewater from this system might be suitable for availability but not as much as could be used again as the water of intended process. One of the methods of wastewater treatment is membrane filtration. Some membrane filters are Micro filter, Ultra filter and Nano filter (McFarlane, 2015).

There is a new experience about a novel sort of membrane which is called Ceramic membrane. This membrane is used more than Carbon filtration because of comfortable cleaning by Return principle. Actually this principle is a process that the flow water is returned periodical. This return flow cause to improve of current flood by removing dirt from surfaces and outlets. Also the $\mathrm{pH}$ of water is important. In lower $\mathrm{pH}$ environment, lower flux and more deposit can be seen than normal pH (Crook, 2004).

Following that, other technique that can be used is Bioreactor Membrane (MBR). This technique is used between other techniques as a process of clearing wastewater. Finally, treated water is used again as water of the process.

\section{Power Plants}

As it is obvious, cooling is an inevitable part in power plants and the cooling process should be done by cold water. Following that, requirement of water in power plants depends on the cooling process demand.
There are three common systems of cooling around the world.

\section{Once-Through Cooling}

This system is more conventional owing to low cost and straightforwardness, although it uses enormous volume of water. Therefore, the required water is supplied from aquifers, lakes or rivers which is inappropriate method environmentally due to the heated water is returned to original resource and it may be polluted in flow of the process.

\section{Once-Through Cooling with Cooling Tower}

The process has the same phases but a cooling tower is embedded through the heated water flow to make it cooler before returning it to the original resource.

\section{Closed Circuit Cooling}

The used water is reused in the cycle again instead of discharge it. Even though some amounts of water would be evaporated in tower, it consumes less water than other systems. The evaporation could withdraw the water based on the local climate.

The Table 2 compares amount of water consumption in diverse plants and systems (Vidic et al., 2009).

According to the stated content and the statistics which were shown in Table 2, every three systems consume huge volume of water. It is worth mentioning that, municipal wastewater could be a not only adequate but also sustainable source. Nevertheless, use of municipal wastewater as a source of cooling system require controlling of the pollutant parameters which lead to corrosion. However, it strongly lean on used metals in the system (Frayne, 1999). Then, quality parameters should be controlled in municipal wastewater which is considered to be reused. The features treated municipal waste water is illustrated in Table 3.

Doubtless, the used pipes in cooling systems should be strong against the characteristics of municipal wastewater (Table 4).

Table 2: Volume of water consumption in different plants and systems

\begin{tabular}{llll}
\hline & & Water intensity (gal/MWh) \\
Plant type & Cooling system & Withdrawal & consumption \\
\hline Fossil/biomass & Once-Through cooling & $20000-50000$ & 300 \\
& Once-Through cooling with cooling tower & $300-600$ & $300-480$ \\
Nuclear & Closed circuit cooling & $500-600$ & 480 \\
& Once-Through cooling & $25000-60000$ & 400 \\
& Once-Through cooling with cooling tower & $500-1100$ & $400-720$ \\
Coal, integrated & Closed circuit cooling & $800-1100$ & 720 \\
gasification combined cycle & Once-Through cooling with cooling tower & 250 & 200 \\
\hline
\end{tabular}


Table 3: Features of treated municipal wastewater for using in a cooling system

\begin{tabular}{|c|c|c|}
\hline Parameters & Proportion $(\mathrm{mg} / \mathrm{L})$ & Detection limit \\
\hline$\overline{\mathrm{Al}}$ & 0.200 & 0.200 \\
\hline $\mathrm{Ca}$ & 42.000 & 5.000 \\
\hline $\mathrm{Cu}$ & 0.028 & 0.100 \\
\hline $\mathrm{Fe}$ & 0.500 & 5.000 \\
\hline $\mathrm{K}$ & 16.300 & 5.000 \\
\hline $\mathrm{Mg}$ & 10.700 & 0.015 \\
\hline $\mathrm{Mn}$ & 0.320 & 5.000 \\
\hline $\mathrm{Na}$ & 94.000 & 1.070 \\
\hline $\mathrm{SiO}_{2}$ & 8.540 & 0.020 \\
\hline $\mathrm{Zn}$ & 0.070 & \\
\hline $\mathrm{pH}$ & 7.100 & 0.500 \\
\hline $\mathrm{NH}_{3}$ & 21.000 & 0.100 \\
\hline $\mathrm{NO}_{3}$ & 3.600 & 5.000 \\
\hline $\mathrm{HCO}_{3}$ Alkalinity & 177.000 & 5.000 \\
\hline Total alkalinity & 177.000 & \\
\hline BOD & 32.000 & 10.000 \\
\hline $\mathrm{Cl}$ & 106.000 & 1.000 \\
\hline $\mathrm{SO}_{4}$ & 86.000 & 0.500 \\
\hline Total P & 4.500 & 1.000 \\
\hline TOC & 27.000 & 10.000 \\
\hline TDS & 661.000 & 5.000 \\
\hline Conductance & 1.030 & 0.010 \\
\hline Turbidity & 16.700 & 1.000 \\
\hline
\end{tabular}

Table 4: Amount of produced pollution in varied steps

\begin{tabular}{lcccr}
\hline Pollutant process & $\mathrm{pH}$ & Conductivity $(\mu \mathrm{S} / \mathrm{m})$ & Rate of turbidity $(\%)$ & TSS $(\mathrm{mg} / \mathrm{L})$ \\
\hline Cleanse of polyester & 7.3 & 544 & 64.0 & 15.2 \\
Double cleanse of polyester & 6.8 & 552 & 59.0 & 2.0 \\
Cleanse of silk & 8.0 & 617 & 28.0 & 11.0 \\
Bleaching of cotton or thread & 8.5 & 1670 & 39.0 & 300.0 \\
Outspread dyeing of polyester & 4.7 & 747 & 4.1 & 2.0 \\
Washing machined polyester & 10.3 & 1096 & 126.0 & 120.0 \\
Dyeing poly amid acid & 7.4 & 830 & 23.0 & 10.0 \\
\hline
\end{tabular}

\section{Textile Industry}

Water is a principal substance for textile industry. It is practically used for cleaning raw materials and various steps of textile dyeing. Factories of this industry, exploit diverse amounts of water depending on process sort. It should be stated that, in textile industry, equipment and management of water using, could cause some changes in water using processes. Therefore, the process of woolen and cotton textiles requires more water than other materials such as polyester and nylon. Then because of this vast usage of water in textile industry, recycle waters is noteworthy (Larsen et al., 2009).

Generally wastewater of textile industry contains following features:

- Decomposable and indecomposable organic materials such as metals, phenols, colors, pesticides, phosphates and certain activate materials.

- High density of Total Suspended Solids (TSS)

- Biological Oxygen Demand (BOD) and Chemical Oxygen Demand (COD)
- Total Dissolved Solids (TDS)

- In following table some processes of this industry and produced pollutants material by these processes are shown

Electro coagulation is one of the methods in treating industrial wastewater. This method is accomplished by using of electrical decomposition of aluminum and iron and producing of coagulant materials. In addition, suspended solids of water are neutralized electrically via producing positive electrical loads by using of electrical flow and installing chemical electrodes such as Aluminum and Iron which operate in the form of anode and cathode (Drewes and Khan, 2011). Concluding, by producing $\mathrm{Al}^{3+}, \mathrm{Fe}^{3+}$, etc. the process of electro coagulation is provided.

\section{Materials and Methods}

In following content, some different methods of wastewater treatment are presented respectively by their purity: 


\section{Biological Treatment}

This method uses natural bacteria to fracture connection of carbon base organic impure material and convert them into unsophisticated compounds. In addition, bacteria uses organic material as a nutrition source, while seed mediators such as sand or polymeric membrane are used to stick or stop bacteria. Therefore, the result of this method could not be completely pure. Bioreactor membranes are common for this sort of treatment.

\section{Filtration}

This method is one of the most expanded methods of treatment which comprises common sand filters to ceramic and polymeric micro filters. Generally, these filters maintain insoluble particles which are measured from millimeter to smaller than micron.

\section{Granule Activate Carbon}

It has known also as carbon filtration method. The granule activate carbon method uses bituminous coal and coconut shell and other organic materials which possess special features to absorb organic compounds. Normally they can be either embedded in the form of profound filters or included in cartridge filters by limited capacity (Cooper, 2001). Carbon filtration also has useful catalytic features to annihilate chlorine compounds. This sort of compounds usually are added to water to control the bacteria's growth, however they should be separated before industrial process.

\section{Softening}

The process of eliminating magnesium and calcium which are water hardness factors. The most practical technique to soften is cation exchange resin that operates in the form of sodium. Hard water is stimulated through the system, then polymeric resin, calcium and sodium will be converted to sodium. This system is active in chemical form. Therefore, it can be used for years simply by vivifying the chloride sodium.

In addition, another method is use of polymeric membrane such as flow path Nano filters that possess feature of softening and cause to conduct hard salt to border of membrane. This method eliminate salt as a chemical reviver-to use in cation exchange- but it wastes too much water unlike repulsed water of flow will be used for other purposes.

\section{Disinfection}

The aim is destruction and control of bacteria and other Microorganism. Chloride compounds and other chemical oxidizing are usually disinfectant. Their location is crucial tip and key factor of this content. If products are sensitive to oxidizing, the chloride compounds should be eliminated. There are diverse ways to prevent surviving bacteria and Microorganisms. UV light can cause weakness and destruction of bacteria in cell level. A combination of UV light treatment with ultrafine filtration and deionization can annihilate bacteria and other Microorganisms effectively.

\section{Case Study}

\section{Kwinana Industrial Area (KIA)}

Industry is one of the largest consumers of water in the west of Australia where $19 \%$ of water of resources is consumed for trade and manufacturing. Following that, Kwinana industrial area is center of industrial activities in Australia. Kwinana industrial area is located 40 kilometers south of Perth in the west of Australia and contains numerous heavy industries which are significant consumers of water. Various sorts of industries are in the area such as Fabrication and Construction facilities as small services and Alumina, Nickel and Oil refineries as some heavy process industries (Harris, 2007).

It is worth mentioning that, KIA used to provide required water from groundwater sources. As result, the amount of water in the sources were reduced and forced the area to provide water from a new resource and recycling wastewaters found out as an ideal option (Anderson, 2003). An appropriate area was needed to respond adequately to sufficient demand security to enable investment in Kwinana Water Recycling Plant (KWRP) and a new pig iron plant provided the requirements. The place was chosen because of two principal reasons.

Firstly, the site was near the ocean output area which supplied initial required water, secondly, it was close to the Kwinana industries.

Every day 24 mega liters is transferred to Kwinana Water Recycling Plant and passed through the microfiltration and reverse osmosis steps. Also the plant receives secondary treated wastewater by woodman point wastewater treatment plant. In each treatment process, 16.7 mega liters which has high quality is transferred to diverse industries in Kwinana industrial area and has lower payments than scheme water. In addition, the plant is able to provide nearly 6 Giga-Liters (GL) of treated wastewater in a year by mentioned methods (Van Beers et al., 2007). This process compensates approximately 2-3\% of drink water in Perth. In 2012-13 treated water reduced 4.6 billion liters of using potable water. The plant has adequate potential of expansion to produce $27 \mathrm{ML} /$ day. Currently, Woodman point and Kwinana wastewater treatment plant are more desirable due to their location and operation. A similar process is used in all treatment plants for principal treating of wastewater (Fig. 3). Activated sludge is used as a secondary treat. However, sequencing batch reactor is applied in Woodman point plant. But, the Oxidation ditch method is operated as secondary treatment in both Kwinana and new East Rockingham (McFarlane, 2015). 
Kaveh Ostad-Ali-Askari and Saeid Eslamian / American Journal of Engineering and Applied Sciences 2021, 14 (1): 94.102 DOI: 10.3844/ajeassp.2021.94.102

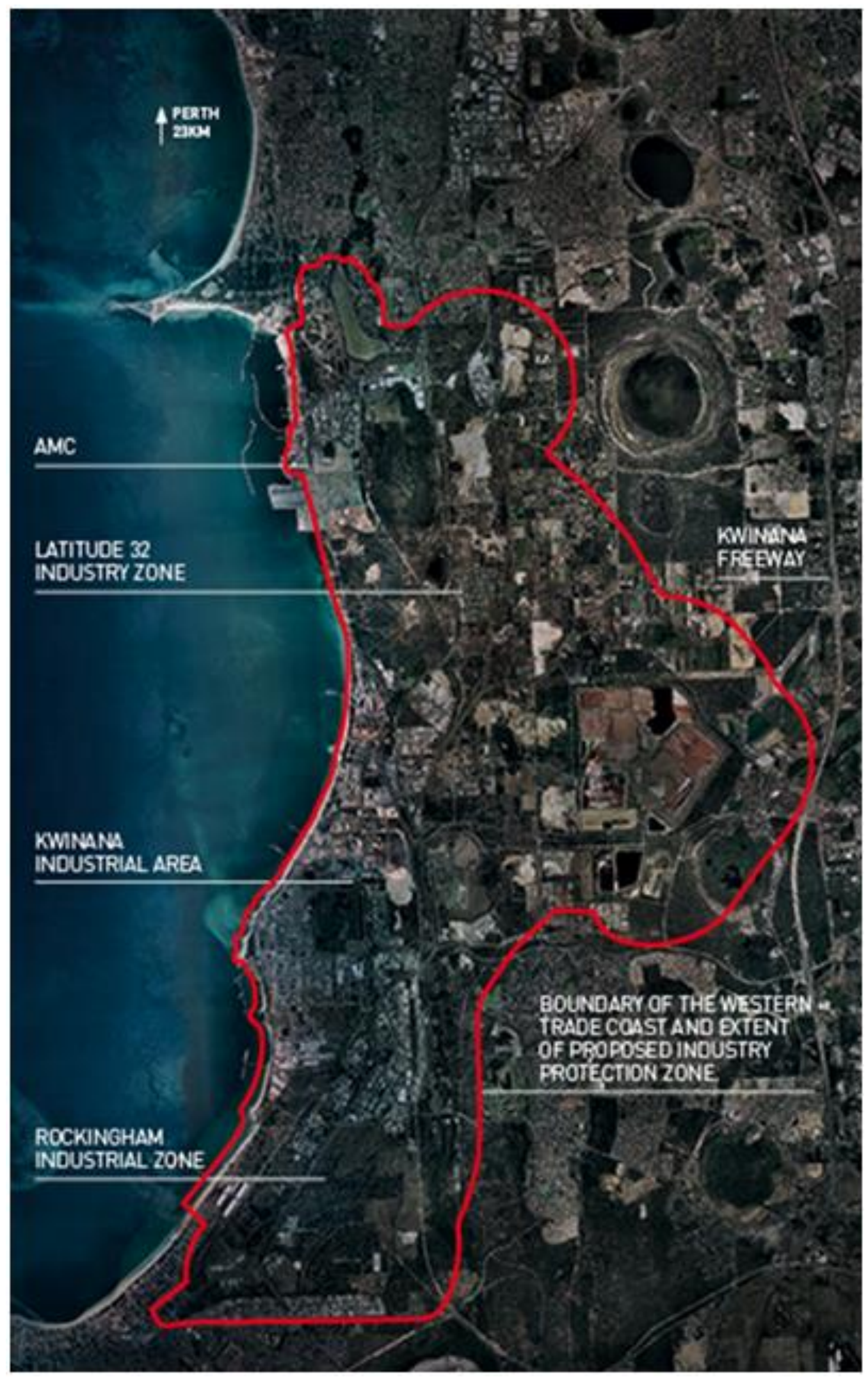

Fig. 3: Satellite image of study area which is located in south of Perth 


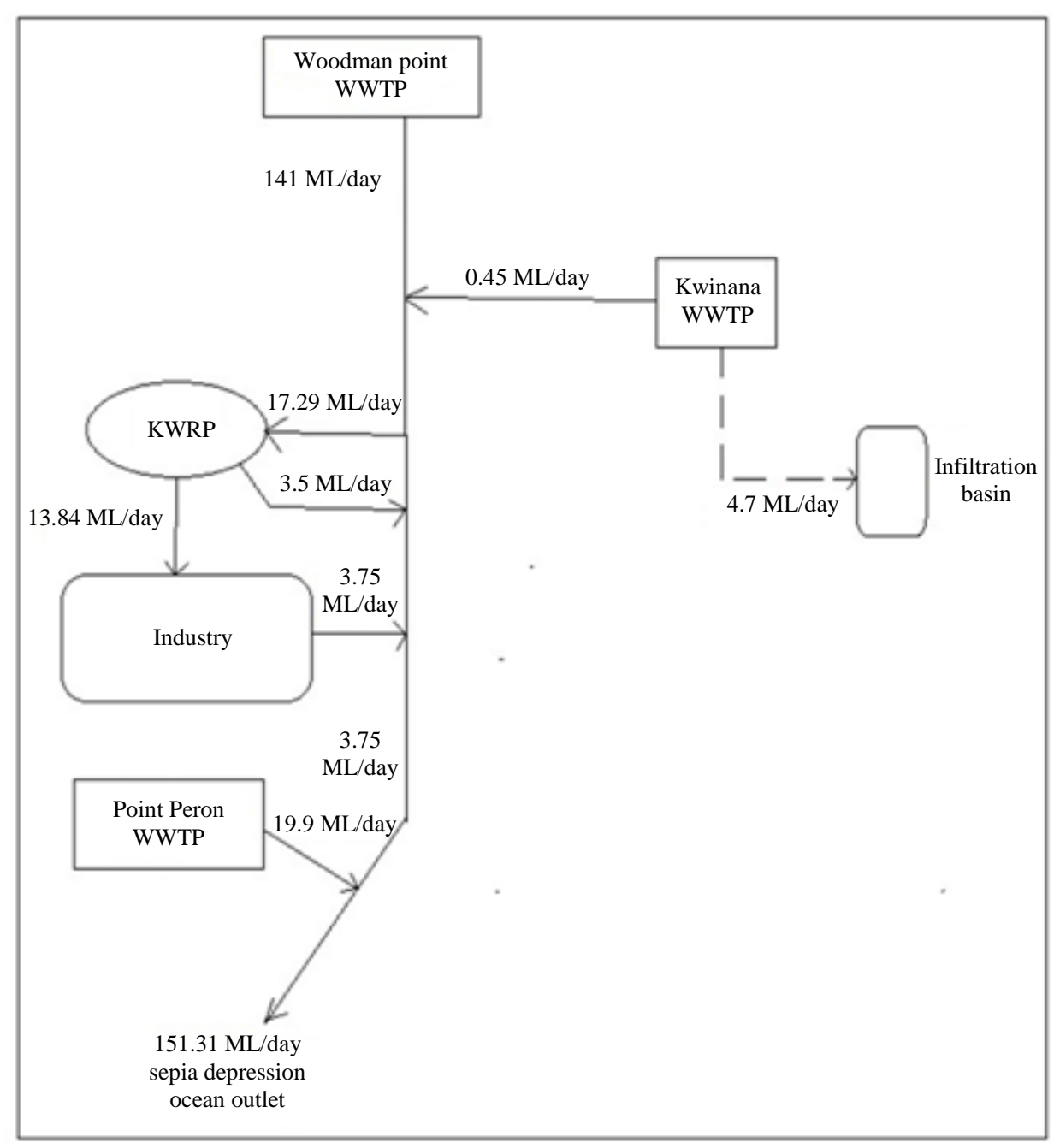

Fig. 4: Input and output of Kwinana wastewater treatment system

As it is obvious in Fig. 4, most of the treated wastewaters is transferred to Sepia depression ocean outlet landline which is located in $4 \mathrm{~km}$ south west of point Peron. Approximately 3\% of treated wastewaters is transferred to infiltration basins. Input and output are schematically shown in Fig. 4.

Pollutants such as heavy metals, pesticides, nutrients and pathogens are observed closely in plants and this process is called monitoring program. The monitoring program makes sure that ecological and environmental values of marine water are retained in area of the Sepia Depression. Also, researches of Water Corporation shows that monitoring process has no harmful influences on marine waters (Harris, 2007). The construction of the project totally cost $\$ 28$ million which is a substantial number but the project will compensate it-self costs by reduction of water using in long term. The Kwinana Water Reclamation Plant received the AWA Environmental Merit Award 2005.

\section{Discussion}

Following that, reuse of water provides not only local, but also trustable source which causes reduction of vulnerability versus drought and other anxieties concerning water sources. Also, it could be tended to economic and environmental benefits. For instance, it can reduce amount of energy using, decrease deviation of stream in rivers and water lanes and decrease pollutions of sewages discharge, While water recycle is a profitable and stable approach in long period of time, wastewater treatment for the reuse and installation and utilization of this type of systems initially can be more costly than other options of saving water. Successful projects of water recycling have been implemented in many countries. These experiences indicate possible of water recycle in large scale and its important role in stable management of universal water sources. 


\section{Conclusion}

In final analysis, this article accomplished a review on using of water in industry and possibility of the reuse in the same industry or in the different one. Experiences of projects and wide studies in health field show water reuse potential to complete drink water sources. A comprehensive approach in urban water plan, sewages and surface runoff can specify opportunities which will never appear without cooperation and comprehensive approach of every parts. Providence in water consuming and the recycle are key elements in comprehensive plan of urban water. Consequently, recycling water will play more important role through the water sources by daily growing of water and environmental requirements. Cooperation with each other and overcome on drawbacks of water recycle with providence in water consumption can assist us in constant management of universal water sources.

\section{Acknowledgment}

We thanks Isfahan University of Technology, Isfahan, Iran.

\section{Author's Contributions}

Arsalan Malekian: Designed the study, collected and analyzed data and wrote the main paper.

Kaveh Ostad-Ali-Askari: Designed the study, collected and analyzed data and wrote the main paper. Edited the manuscript, wrote the Supplementary Information and accomplished the final revise.

Saeid Eslamian: Designed the study, collected and analyzed data and wrote the main paper. Interpreted and developed the gathered data, gave technical support and conceptual advice.

Shahide Dehghan, Vijay P. Singh, Nicolas R. Dalezios and Mohammad Reza Afghari: Contributed extensively to the work presented in this study.

\section{Ethics}

This study was approved by Isfahan University of Technology, Isfahan, Iran.

\section{References}

Abdel-Shafy, H. I., \& Mansour, M. S. (2013). Overview on water reuse in Egypt: present and future. J. Sustainable Sanitation Practice, 14, 17-25.

Anderson, J. (2003). The environmental benefits of water recycling and reuse. Water Science and Technology: Water Supply, 3(4), 1-10.

Asano, T., Burton, F. L., Leverenz, H. L., Tsuchihashi, R., Tchobanoglous, G., \& r Reuse, W. (2006). Issues, Technologies and Applications.
Bilotta, P., Steinmetz, R. L. R., Kunz, A., \& Mores, R. (2017). Swine effluent post-treatment by alkaline control and UV radiation combined for water reuse. Journal of Cleaner Production, 140, 1247-1254.

Cooper, P. F. (2001). Historical aspects of wastewater treatment. Decentralised Sanitation and Reuse.

Drewes, J. E., \& Khan, S. J. (2011). Water reuse for drinking water augmentation. Water quality and treatment, 16-1.

Eslamian, A., Eslamian, F., \& Eslamian, S. (2015a). Water Reuse Guidelines for Industry. Urban Water Reuse Handbook, 187-194.

Eslamian, S. K., Saadati, M. M., \& Esfahany, S. T. (2015b). Urban Water Reuse in Industry. In: Urban Water Reuse Handbook, Eslamian, S. (Ed.), Taylor and Francis, USA, pp: 137-142.

Frayne, C. (1999). Cooling water treatment: Principles and practice. New York: Chemical Publishing Company.

Gohari, A., Eslamian, S., Mirchi, A., Abedi-Koupaei, J., Bavani, A. M., \& Madani, K. (2013). Water transfer as a solution to water shortage: a fix that can backfire. Journal of Hydrology, 491, 23-39.

Harris, S. (2007). Industrial symbiosis in the Kwinana industrial area (Western Australia). Measurement and Control, 40(8), 239-244.

Illungkoo, K., \& Vigneswaran, S. (1998). Wastewater reuse, recycle and reclamation. Water Reuse for Agriculture.

Crook, J. (2004). Innovative applications in water reuse: Ten case studies. WateReuse Association.

Larsen, T. A., Alder, A. C., Eggen, R. I., Maurer, M., \& Lienert, J. (2009). Source separation: will we see a paradigm shift in wastewater handling?.

Lazarova, V., Levine, B., Sack, J., Cirelli, G., Jeffrey, P., Muntau, H., ... \& Brissaud, F. (2001). Role of water reuse for enhancing integrated water management in Europe and Mediterranean countries. Water Science and Technology, 43(10), 25-33.

Mattioli, D., De Florio, L., Giordano, A., Tarantini, M., Scalbi, S., Aguado, M. M., ... \& De Vresse, I. (2005). Efficient use of water in the textile finishing industry. E-Water, European Water Association (EWA), 3-4.

McFarlane, D. J. (2015). Recycled water for heavy industry and preventing sea water intrusion.

Van Beers, D., Oughton, C., \& Cooling, D. (2007). Update on regional synergy development in the Kwinana industrial area. Proceedings of the SSEE International Conference on Engineering Sustainability, Perth, Australia.

Vidic, R., Dzombak, D., Hsieh, M. K., Li, H., Chien, S. H., Feng, Y., ... \& Monnell, J. (2009). Reuse of treated internal or external wastewaters in the cooling systems of coal-based thermoelectric power plants. University of Pittsburgh.

Williams, R. B. (1982). Wastewater reuse-an assessment of the potential and technology. Water reuse/edited by E. Joe Middlebrooks. 